\title{
PENGARUH KEPEMIMPINAN KEPALA SEKOLAH DAN MOTIVASI KERJA TERHADAP KINERJA GURU SD NEGERI SE KECAMATAN DUMAI BARAT KOTA DUMAI
}

\author{
Syafruddin ${ }^{1}$, Isjoni $^{1 \star}{ }^{\star}$, Afrianto $^{2}$ \\ ${ }^{1}$ Magister Administrasi Pendidikan, Program Pascasarjana Universitas Riau, \\ Pekanbaru, Indonesia \\ ${ }^{2}$ Program Studi Pendidikan Bahasa Inggris, Fakultas Keguruan dan IImu Pendidikan, \\ Universitas Riau, Pekanbaru, Riau \\ *isjoni@lecturer.unri.ac.id
}

\begin{abstract}
The purpose of this study was to determine the effect of principal's leadership and teacher's work motivation, either individually or jointly on employee performance. The research was conducted in SDN in Dumai Barat sub-district, Dumai City with the research subjects being teachers in SDN in Dumai Barat sub-district, Dumai City, the method used was a survey with correlation technique, the research sample was teachers at SDN in the sub-district of West Dumai City. Dumai totaling 150. The instrument used to collect data on principals' leadership, work motivation and performance was using a questionnaire. The validity of the test items using the product moment formula and the instrument reliability coefficients were calculated using the Cronbach alpha formula. The results of this study indicate that: 1) there is a significant and positive influence between the principal's leadership on performance; 2) there is a significant and positive effect between teacher work motivation on performance; 3) there is a significant and positive influence between the principal's leadership and the work motivation of teachers on performance together. The results of this study are expected to be useful for the improvement and improvement of the performance of principals and teachers in public elementary schools throughout the West Dumai sub-district, Dumai City.
\end{abstract}

Keywords: leadership, performance; work motivation

\section{PENDAHULUAN}

Membicarakan tentang pendidikan yang berkualitas, tentu saja mengharuskan adanya keterpaduan dari semua komponen pendidikan yang saling berkaitan. Komponen-komponen tersebut antara lain: pendidikan yang saling berkaitan, peserta didik, kurikulum, sarana dan prasarana. Suatu satuan pendidikan akan dapat mencapai tujuannya apabila personilnya dapat membangun jalan kerjasama demi terwujudnya visi dan misi sekolah yakni meningkatkan kualitas anak didik. 
Aktivitas kerjasama tersebut dilaksanakan antara kepala sekolah, guru, serta karyawan bahkan dengan para siswa (sari \& Isjoni, 2021).

Guru adalah figur terdepan dalam melakukan perubahan paradigma pendidikan kemudian sosok yang merupakan salah satu unsur penting bagi keberhasilan pembelajaran (Putra, 2019). Guru mengajar dan bekerja di sekolah diharapkan dapat bekerja dengan penuh antusias, penuh inisiatif, penuh gairah serta dengan kemauan yang tinggi. Semangat kerja yang tinggi dari guru dimanifestasikan dalam bentuk kreativitas dan iniisiatif dalam menyelenggarakan proses pembelajaran, yang apabila dilakukan dengan baik akan dapat menghasilkan kinerja yang baik pula.

Berbicara tentang kinerja guru erat kaitannya dengan cara penilaian terhadap pekerjaan seorang guru sehinigga perlu diterapkan standar penilaian. Kinerja guru dipengaruhi oleh banyak faktor, baik langsung maupun tidak langsung. Diantaranya gaya dan prilaku kepemimpinan (style and behavior leadership) dalam hal ini kepala sekolah. Pengaruh dan kekuasaan kepemimpinan (power and influence leadership). Motivasi (motivation), kepercayaan (trust), dan pengambilan keputusan (decision making).

Kepala sekolah adalah jabatan pemimpin yang tidak bisa diisi oleh orang tanpa didasarkan atas pertimbangan. Siapa pun yang akan diangkat menjadi kepala sekolah harus ditentukan melalui prosedur serta persyaratan tertentu seperti latar belakang pendidikan, pengalaman, usia, pangkat dan integritas. Oleh sebab itu, kepala sekolah pada hakikatnya adalah pejabat formal sebab pengangkatannya melalui suatu proses dan prosedur yang didasarkan atas peraturan yang berlaku.

Fenomena yang terlihat menunjukkan rendahnya kinerja guru SD Negeri Kecamatan Dumai Barat Kota Dumai ini. Ini dibuktikan berdasarkan hasil wawancara dan diskusi dengan kepala sekolah, wakil kepala sekolah dan para siswa. Informasi tersebut penulis kumpulkan sehingga patut diduga bahwa berdasarkan penomena tersebut menunjukkan buruknya kinerja guru yang diukur dari, dari sub unsur pelaksanaan proses pembelajaran/pembimbingan dan tugas tambahan yang relevan sebagai berikut: 1) Yang relevan dengan fungsi sekolah didasarkan atas aspek kualitas, kuantitas, waktu dan/atau biaya, yang dilaksanakan secara obyektif dan 
berkelanjutan; 2) Yang mengacu pada 4 domain kompetensi (pedagogik, sosial, profesional, dan kepribadian) dalam sistem paket menggunakan instrumen Penilaian Kinerja Guru (PKG) dengan skala nilai 1 sampai dengan 4 sebagaimana tercantum pada Format 1; 3) Penilaian didasarkan Sistem Paket meliputi sub unsur melaksanakan proses pembelajaran pembimbingan dan tugas tambahan yang relevan dengan fungsi sekolah. Angka kreditnya dihitung sebagai berikut: (a) Penilaian proses pembelajaran pembimbingan mencakup aspek perencanaan dan pelaksanaan, pembelajaran pembimbingan, evaluasi dan penilaian, analisis hasil penilaian, dan pelaksanaan tindak lanjut hasil penilaian; (b) Penilaian pelaksanaan tugas tambahan atau tugas lain yang relevan dengan fungsi sekolah mencakup aspek-aspek yang sesuai dengan kompetensi atau tugas pokok dan fungsinya; (c) Penilaian kinerja guru dilakukan oleh kepala sekolah dengan menggunakan instrument penilaian kinerja guru dan wajib dilakukan setiap tahun; (d) Penilaian kinerja guru yang diberi tugas tambahan sebagai kepala sekolah dilakukan oleh pengawas sekolah yang relevan dengan menggunakan instrumen Penilaian Kinerja Guru (PKG) dan instrumen Penilaian Penilaian Kinerja Kepala Sekolah (PKKS); (e) Penilaian kinerja guru yang diberi tugas tambahan yang relevan dengan fungsi sekolah dilakukan oleh kepala sekolah dengan aturan yang telah ditetapkan. 4) Penilaian kinerja dengan sistem paket menggunakan instrumen PKG sub unsur pembelajaran atau pembimbingan.

Tetapi semua fenomena tersebut menunjukan hal sebaliknya yaitu : sebagian guru tidak menunjukkan kinerja yang maksimal yaitu dalam memenuhi tugasnya mengajar dengan jumlah jam mengajar yang ditetapkan, pada saat lonceng pergantian jam guru masih berada di kantor dan berbincang-bincang dengan guru lain sehingga anak didik datang menjemput guru di kantor menyatakan kelas mereka tidak ada guru, dan hal lain pada saat pelajaran telah dimulai guru tidak memiliki persiapan materi pembelajaran sehingga siswa diperintahkan mengerjakan tugas sekolah dengan mencatat dari papan tulis sementara guru pergi sarapan bagi ke kantin, tidak kreatifnya guru sehingga proses belajar yang selalu monoton tanpa menggunakan media dan kelas selalu model klasikal, jarangnya memberikan motivasi kepada siswa agar memiliki semangat belajar yang lebih baik. 
Disamping itu guru jarang mengevaluasi dan menindak lanjuti evaluasi agar dapat mendata anak yang memahami materi dan anak yang kurang dalam pembelajaran, tugas yang diberikan kesiswa kurang menantang dan monoton, kurangnya kualitas pertanyaan yang diberikan kesiswa sehingga siswa tidak tertarik menjawab pertanyaan guru, pilih kasih kepada anak didik, dan cara guru menjawab, pertanyaan dari murid kurang sopan, tulisan dipapan tulis terlalu kecil sehingga siswa susah melihat tulisan, hal ini menyebabkan murid berlomba-lomba melihat tulisan mengakibatkan suasana kelas jadi gaduh, dan yang paling buruk adalah mengakibatkan tidak tercapainya tujuan pembelajaran.

Berdasarkan rumusan masalah tersebut maka penelitian sebagai berikut:

1. Apakah kepemimpinan kepala sekolah berpengaruh terhadap kinerja guru?

2. Apakah motivasi kerja berpengaruh terhadap kinerja guru?

3. Apakah kepemimpinan kepala sekolah dan motivasi guru berpengaruh terhadap kinerja guru?

Maka penelitian ini dilakukan dengan tujuan:

1. Untuk mendeskripsikan pengaruh kepemimpinan kepala sekolah terhadap kinerja di SD Negeri Kecamatan Dumai Barat Kota Dumai,

2. Untuk mendeskripsikan pengaruh motivasi kerja terhadap kinerja di SD Negeri Kecamatan Dumai Barat Kota Dumai.

3. Untuk mendeskripsikan pengaruh kepemimpinan kepala sekolah dan motivasi kerja terhadap kinerja guru di SD Negeri Kecamatan Dumai Barat Kota Dumai.

Penelitian ini sekiranya dapat diharapkan bermanfaat

a. Bagi penulis, dapat menambah pengetahuan sebagai bekal dalam menerapkan ilmu yang telah diperoleh dibangku kuliah dalam dunia kerja yang sesungguhnya.

b. Dapat memberikan sumbangan ilmu pengetahuan tentang gaya kepemimpinan kepala sekolah, motivasi dan kinerja kerja.

Rivai dan Murni (2008) menjelaskan bahwa kinerja merupakan prestasi yang dicapai seseorang dalam melaksanakan tugasnya atau pekerjaannya sesuai dengan standar dan kriteria yang ditetapkan untuk pekerjaan itu. Senada dengan pendapat Husaini (2010:489) bahwa kinerja adalah produk yang dihasilkan oleh seseorang pegawai dalam satuan waktu yang telah ditentukan dengan kriteria tertentu pula. 
Produknya dapat berupa layanan jasa atau barang. Hal ini menunjukkan bahwa dalam menentukan prestasi ditentukan berdasarkan pencapaian melebihi standar/ kriteria atau hanya mencapai standar.

Kinerja seseorang dikatakan baik apabila hasil kerja individu tersebut dapat melampaui peran atau target yang ditentukan sebelumnya. Selanjutnya Simamora (2004:339) mempertegas bahwa kinerja (Performance) mengacu kepada kadar pencapaian tugas-tugas yang membentuk sebuah pekerjaan karyawan. Kinerja merefleksikan seberapa baik karyawan memenuhi persyaratan sebuah pekerjaan. Pendapat lain tentang kinerja adalah bahwa kinerja (performance) pada dasarnya adalah apa yang dilakukan oleh karyawan (Manthis \& Jackson 2011).

Guru yang memiliki kinerja yang baik dapat dikatakan sebagai guru profesional atau pendidik yang baik. Sebagai seorang tenaga profesional, seorang guru mempunyai tugas pokok dan fungsinya yaitu bertanggung jawab kepada Kepala Sekolah dalam melaksanakan Kegiatan Belajar Mengajar (KBM), yang meliputi:

1) Membuat kelengkapan mengajar dengan baik dan lengkap

2) Melaksanakan kegiatan pembelajaran

3) Melaksanakan kegiatan penilaian proses belajar, ulangan harian, ulangan umum, dan ujian akhir

4) Melaksanakan analisis hasil ulangan harian

5) Menyusun dan melaksanakan program perbaikan dan pentipe an

6) Mengisi daftar nilai anak didik

7) Melaksanakan kegiatan membimbing (pengimbasan pengetahuan), kepada guru lain dalam proses pembelajaran

8) Membuat alat pelajaran/alat peraga

9) Menumbuh kembangkan sikap menghargai karya seni

10)Mengikuti kegiatan pengembangan dan pemasyarakatan kurikulum

11)Melaksanakan tugas tertentu di sekolah

12) Mengadakan pengembangan program pembelajaran

13)Membuat catatan tentang kemajuan hasil belajar anak didik

14)Mengisi dan meneliti daftar hadir sebelum memulai pelajaran

15) Mengatur kebersihan ruang kelas dan sekitarnya 
16) Mengumpulkan dan menghitung angka kredit untuk kenaikan pangkat.

Nuraini, et.al, menyebutkan masih ditemukan guru yang memiliki kinerja yang rendah dengan tidak menyusun sendiri silabus, rencana pembelajaran, tes yang terstandar dan perangkat pengajaran lainnya. Sanusi dkk. (1999) menjelaskan bahwa kinerja guru dapat dirinci empat fungsi

Pertama, merencanakan PBM seperti perumusan tujuan instruksional, menguraikan dan mendiskripsikan satuan pokok bahasan, merancang KBM, pemilihan media dan sumber belajar serta penyusunan instrumen evaluasi.

Kedua adalah melaksanakan dan memimpin PBM mencakup kegiatan: pembimbingan dan pengarahan PBM, pengaturan dan pengubahan suasana belajar-mengajar, penetapan dan pengubahan urutan KBM.

Ketiga, menilai kemajuan belajar yang meliputi pemberian skor hasil evaluasi, pentransformasian skor menjadi nilai serta penetapan peringkat.

Keempat adalah guru menafsirkan dan memanfaatkan berbagai informasi basil penilaian dan penelitian untuk memecahkan masalah profesional kependidikan.

Kinerja tentunya dipengaruhi oleh banyak faktor. Menurut Wibowo (2007), kinerja pekerja dipengaruhi oleh: (a) pengetahuan, kemampuan dan sikap; (b) gaya kerja, kepribadian, kepentingan/minat, dasar-dasar, nilai, sikap, kepercayaan dan gaya kepemimpinan. Sementara implementasi kinerja dilakukan oleh sumber daya manusia yang memiliki kemampuan, kompetensi, motivasi dan kepentingan. Kinerja yang tinggi dihasilkan dari prilaku yang sesuai, dipengaruhi pengetahuan, keterampilan dan kompetensi.

Dari pendapat di atas dapat ditarik sintesis yaitu bahwa kinerja guru adalah tingkat keberhasilan yang dicapai oleh guru dalam melaksanakan dan menyelesaikan tugas-tugas yang dibebankan kepadanya sesuai dengan tanggung jawab untuk mencapai tujuan yang telah ditetapkan, dengan indikator: (1) pedagogik, (2) kepribadian, (3) sosial, dan (4) profesional.

Menurut Soehardi (1983) Kepemimpinan adalah hubungan dimana di dalamnya antara orang dan pemimpin saling mempengaruhi agar mau bekerja sama membagi tugas untuk mencapai keinginan sang pemimpin. Ada banyak definisi kepemimpinan yang dikemukakan oleh pakar menurut sudut pandang masing- 
masing. Banyaknya definisi kepemimpinan hampir sama jumlahnya dengan mereka yang mendefinisikannya, walaupun tidak dapat dipungkiri bahwa ada kesamaan di dalam definisi tersebut.

Rivai (2009) dalam bukunya yang berjudul "Kepemimpinan dan Perilaku Organisasi" menyatakan bahwa definisi kepemimpinan secara luas, adalah meliputi proses mempengaruhi dalam menentukan tujuan organisasi, memotivasi perilaku pengikut untuk mencapai tujuan, mempengaruhi interprestasi mengenai peristiwaperistiwa para pengikutnya, pengorganisasian dan aktivitas-aktivitas untuk mencapai sasaran, memelihara hubungan kerja sama dan kerja kelompok, perolehan dukungan dan kerja sama dari orang-orang di luar kelompok atau organisasi.

Dari berbagai pengertian diatas dapat ditarik kesimpulan bahwa pengertian kepemimpinan merupakan suatu cara seorang pemimpin dalam usahanya untuk mempengaruhi bawahannya agar mau bekerja sama untuk mencapai tujuan organisasi.

Kepemimpinan kepala sekolah adalah cara atau usaha kepala sekolah dalam mempengaruhi, mendorong, membimbing, mengarahkan, dan menggerakkan guru, staf, siswa, orang tua siswa, dan pihak lain yang terkait, untuk bekerja/berperan serta guna mencapai tujuan yang telah ditetapkan. Singkatnya, cara kepala sekolah untuk membuat orang lain bekerja untuk mencapai tujuan sekolah (Dirjen Dikdasmen, 1998).

Berdasarkan uraian-uraian sebelumnya, maka dapat disimpulkan bahwa indikator kepemimpinan Kepala Sekolah yang efektif dalam penelitian ini terdiri dari 1) memiliki visi, 2) memiliki harapan, 3) memiliki program yang positif dan kosturktif 4) memanfaatkan waktu, 5) mendayagunakan sumber belajar dan seluruh warga sekolah, 6) memantau kemajuan peserta didik dan 7) melakukan evaluasi berkesinambungan.

Winardi (2002:102) menyatakan bahwa : "Motivasi adalah suatu kekuatan potensial yang ada dalam diri seseorang manusia, yang dapat dikembangkannya sendiri, ataudikembakan oleh sejumlah kekuatan luar, yang pada intinya berkisar sekitar imbalan moneter, dan imbalan nonmoneter yang dapat mempengaruhi hasil 
kinerjanya secara positif atau secara negatif, hal mana tergantung pada situasi dan konsisi yang dihadapi oleh yang bersangkutan".

Menurut Hoy and Misker (1991:168), Motivasi kerja didefinisikan sebagai kekuatan, dorongan, kebutuhan, pernyataan, ketegangan, atau mekanisme lain untuk memulai atau memelihara perilaku hubungan kerja terhadap pencapaian tujuan pribadi. Definisi tersebut menggambarkan bahwa motivasi terdiri dari kekuatan-kekuatan untuk memulai dan memelihara tindakan sukarela yang diupayakan untuk mencapai tujuan pribadi.

McShane and Glinow (2008:134) menyatakan bahwa motivasi kerja berkenaan dengan kekuatan-kekuatan dalam diri seseorang yang mempengaruhi arah, intensitas, dan berkelanjutan secara sukarela. Motivasi itu adalah keinginan dengan mengkerahkan segala tenaga (intensitas) dalam waktu tertentu (berkelanjutan) terhadap sebuah tujuan tertentu (direksi).

Berdasarkan dari uraian teori-teori diatas, maka dapat disintesiskan bahwa motivasi kerja adalah suatu dorongan yang menggerakkan seseorang dalam melaksanakan tugas yang bersumber dari dalam dirinya maupun yang diluar dirinya guna mencapai hasil kerja yang memuaskan dan bila dihubungkan dengan penelitian ini maka motivasi adalah suatu dorongan yang menggerakkan guru dalam melaksanakan tugas yang bersumber dari dalam dirinya maupun diluar dirinya guna mencapai Kinerja yang memuaskan, dengan indikator : (1) tanggung jawab, (2) kerjasama, (3) memiliki keinginan untuk maju, dan (4) semangat dalam bekerja.

\section{METODE PENELITIAN}

Penelitian akan dilaksanakan di Kecamatan Dumai Barat Kota Dumai. Waktu pelaksanaan penelitian dimulai dari Pebruari sampai dengan Mei 2021. Penelitian ini menggunakan pendekatan kuantitatif dengan metode Survey dengan teknik korelasional (correlational resarch) yaitu studi korelasi yang bertujuan untuk menguji hipotesis. Hal ini dilakukan dengan cara mengukur sejumlah variabel dan menghitung korelasi antara variabel-variabel mana yang berkorelasi.

Instrumen penelitian yang digunakan untuk pengumpulan data adalah angket. Dalam penelitian ini terdapat tiga variabel penelitian yaitu dua variabel bebas 
(Independen Variable) yang terdiri dari Kepemimpinan Kepala Sekolah $\left(\mathrm{X}_{1}\right)$, dan motivasi kerja $\left(\mathrm{X}_{2}\right)$, serta satu variabel terikat (Dependent Variable) yaitu Kinerja guru guru $(Y)$.

Populasi dalam penelitian ini adalah guru Sekolah Dasar Negeri di Kecamatan Dumai Barat Kota Dumai dengan jumlah populasi sebanyak 238 orang guru. Sampel sebanyak 150 guru sebagai responden.

Pengambilan sampel pada penelitian ini dilakukan dengan dengan teknik Simple Random Sampling. Kemudian untuk keperluan uji coba dilakukan dengan mengambil sisa sampel dari guru SDN di Kecamatan Dumai Barat Kota Dumai sebanyak 30 orang, dengan cara undian.

Penyusunan alat ukur dimulai dengan pembuatan tabel spesifikasi skala indikator kepemimpinan kepala sekolah, motivasi kerja, dan kinerja guru. Butir item meliputi pernyataan positif (favorabel) dan pernyataan negative (unforabel). Butir item dinyatakan layak sebagai alat ukur jika sudah diuji validitas dan realibilitasnya. Maka untuk menentukan kelayakan alat ukur tersebut, item-item pernyataan dikenai uji validitas dan realibilitas. Alternative yang disediakan peneliti dalam skala ini yaitu Selalu (SL), Sering (SR), Kadang-Kadang (KK), Jarang (JR), dan Tidak Pernah (TP), dengan skala nilai 5, 4, 3, 2, dan 1. Kemudian jawaban item negatif Selalu (SL), Sering (SR), Kadang-Kadang (KK), Jarang (JR), dan Tidak Pernah (TP), dengan skala nilai $1,2,3,4$, dan 5 . Pengumpulan data yang digunakan penulis dengan menggunakan Angket

Uji validitas dan reliabilitas instrumen dengan menggunakan rumus Korelasi Product Moment, Alpha Cronbch, berturut turut. Teknik analisis data yang dilakukan adalah analisis deskriptif dan analisis korelasi. Penghitungan uji validitas dan realibilitas ini menggunakan bantuan Statistical Package for the Social Science (SPSS).

Teknik analisis data yang digunakan dalam penelitian ini adalah analisis statistik deskriptif dan analisis statistik inferensial. Pengolahan data untuk analisis statistik deskriptif dalam penelitian ini menggunakan program Microsoft Excel dan SPSS versi 17 for Windows. Pengolahan data untuk kedua uji tersebut dilakukan dengan bantuan program SPSS. 


\section{HASIL DAN PEMBAHASAN}

\section{Hasil Penelitian}

Sebagai alat analisis uji validitas digunakan teknik korelasi Product Moment. Berikut ini disajikan hasil uji validitas instrumen berdasarkan hasil perhitungan dengan menggunakan SPSS 20.

Diperoleh hasil signifikansi variabel kinerja guru $(\mathrm{Y})$ berdistribusi normal, karena nilai sig lebih besar dari nilai alpa $(0,200>0,05)$, variabel kepemimpinan kepala sekolah $\left(X_{1}\right)$ berdistribusi normal karena sig lebih besar dari nilai alpha $(0,092$ $>0,05)$, dan variabel motivasi kerja $\left(X_{2}\right)$ juga berdistribusi normal, karena nilai sig lebih besar dari nilai alpa $(0,075>0,05)$. Nilai signifikansi masing-masing variabel ini $>0,05$ yang berarti bahwa $\mathrm{H}_{0}$ diterima atau data dari masing-masing variabel berdistribusi normal. Dengan demikian, persyaratan analisis regresi terpenuhi.

Karena nilai signifikansi (Sig.) pada baris linierity adalah 0,000 yang berarti < 0,05 . Oleh sebab itu, analisis yang digunakan pada uji hipotesis adalah linier. Dengan demikian, persyaratan analisis regresi terpenuhi.

Diketahui koefiesien korelasi antara kepemimpinan kepala sekolah dengan kinerja guru adalah 0,709 . Koefesien Determinasi $\left(r^{2}\right)=(0,709)^{2}$ adalah 0,503 atau $50,3 \%$ artinya besarnya pengaruh kepemimpinan kepala sekolah terhadap kinerja guru adalah $50,3 \%$ sedangkan sisanya dipengaruhi oleh faktor lain. Ini berarti bahwa variabel $X_{1}$ mempunyai pengaruh yang cukup tinggi terhadap variabel $Y$.

Selanjutnya diketahui koefiesien korelasi antara motivasi kerja terhadap kinerja guru adalah 0,821 . Koefesien Determinasi $\left(r^{2}\right)=(0,821)^{2}$ adalah 0,674 atau 67,4\% artinya besarnya motivasi kerja terhadap kinerja guru adalah 67,4\% sedangkan sisanya dipengaruhi oleh faktor lain. Ini berarti bahwa variabel $\mathrm{X}_{2}$ mempunyai pengaruh yang tinggi terhadap variabel $Y$. Setelah itu koefisien korelasi antara kepemimpinan kepala sekolah dan motivasi kerja dengan kinerja guru adalah 0,848 . Koefesien Determinasi $\left(r^{2}\right)=(0,848)^{2}$ adalah 0,720 atau $72 \%$ artinya besarnya pengaruh kepemimpinan kepala sekolah dan motivasi kerja dengan kinerja guru adalah $72 \%$, sedangkan sisanya dipengaruhi faktor lain. Ini berarti bahwa variabel $X_{1}$ dan $X_{2}$ mempunyai pengaruh yang tinggi terhadap variabel $Y$. 


\section{Pembahasan Penelitian}

\section{Pengaruh Kepemimpinan Kepala Sekolah $\left(\mathrm{X}_{1}\right)$ terhadap Kinerja Guru $(\mathrm{Y})$}

Untuk pengaruh yang terjadi pada kepemimpinan kepala sekolah terhadap kinerja guru, koefisien regresi yang terbentuk yaitu sebesar 0,709 yang mengartikan kekuatan pengaruh antar kepemimpinan kepala sekolah terhadap kinerja guru adalah kuat. Dari hasil perhitungan koefisien determinasi diperoleh $r_{x 1 . y}=0,709^{a}=$ 0,709 atau $70,9 \%$. Ini berarti sebesar $70,9 \%$ variansi kinerja guru dapat dijelaskan oleh kepemimpinan kepala sekolah melalui persamaan regresi $Y=33,768+0,511$ $X_{1}$. Persamaan regresi $Y=33,768+0,511 X_{1}$ mempunyai arti bahwa setiap peningkatan satu satuan skor kepemimpinan kepala sekolah maka diikuti oleh kenaikan skor kinerja guru sebesar 0,511 pada konstanta 33,768.

Untuk menguji signifikansi regresi antara kepemimpinan kepala sekolah $\left(\mathrm{X}_{1}\right)$ terhadap kinerja guru ( $\mathrm{Y}$ ) digunakan rumus uji t. Harga t hitung sebesar 12,231. Sedangkan harga $t$ tabel untuk menguji dua pihak dengan $d k=147, \alpha=0,05$ diperoleh harga $t$ tabel sebesar 1,655. Karena 12,231 $>1,655 \mathrm{t}$ hitung $=12,231>t$ tabel 1,655 maka dapat disimpulkan bahwa terdapat hubungan yang signifikan, dengan demikian hipotesis nol $\left(\mathrm{H}_{0}\right)$ ditolak, sebaliknya alternatif $\left(\mathrm{H}_{\mathrm{a}}\right)$ diterima. Kesimpulannya adalah terdapat pengaruh yang signifikan antara kepemimpinan kepala sekolah $\left(\mathrm{X}_{1}\right)$ terhadap kinerja guru $(\mathrm{Y})$.

Kemudian dari hasil $\mathrm{F}$ hitung 149,595 $>\mathrm{F}$ tabel 3,06, dengan taraf signifikansi 0,05 , maka $\mathrm{H}_{0}$ ditolak. Dengan demikian hipotesis pertama dalam penelitian ini diterima, yang artinya terdapat pengaruh yang signifikan antara kepemimpinan kepala sekolah terhadap kinerja guru.

Pengaruh kepemimpinan kepala sekolah terhadap kinerja guru menunjukkan hasil koefisien regresi yang positif dan signifikan. Ini berarti bahwa jika kepemimpinan kepala sekolah baik, maka kinerja guru akan semakin baik/meningkat.

Hasil ini sesuai dengan penelitian yang dilakukan oleh Sumarno (2009). Hasil penelitian menunjukkan bahwa : terdapat pengaruh positif dan signifikan kepemimpinan kepala sekolah terhadap kinerja guru SD Negeri Kecamatan 
Paguyangan sebesar $25,8 \%$, profesionalisme berpengaruh positif dan signifikan terhadap kinerja guru dengan koefisien determinasi sebesar 39,4\%. Hasil analisis regresi berganda menunjukkan adanya pengaruh bersama-sama secara positif dan signifikan kepemimpinan kepala sekolah dan profesionalisme guru terhadap kinerja guru SD Negeri Kecamatan Paguyangan dengan koefisien determinasi sebesar $43,8 \%$.

Hasil penelitian sesuai dengan pendapat Barnawi (2012) faktor - faktor yang mempengaruhi kinerja guru yakni : faktor internal kinerja guru adalah faktor yang datang dari dalam diri guru yang dapat mempengaruhi kinerjanya, contohnya ialah kemampuan, keterampilan, kepribadian, persepsi, motivasi menjadi guru, pengalaman lapangan dan latar belakang keluarga. Sedangkan faktor eksternal kinerja guru adalah faktor yang datang dari luar guru yang dapat mempengaruhi kinerjanya, contohnya ialah (1). Gaji (2). Sarana dan prasarana (3). Lingkungan kerja fisik (4). Kepemimpinan kepala sekolah.

Dengan demikian kepemimpinan kepala sekolah yang baik di Sekolah Dasar Negeri di Kecamatan Dumai Barat Kota Dumai, maka kinerja guru akan semakin baik pula. Hal ini dibuktikan dengan hasil analisis regresi bahwa koefisien kepemimpinan kepala sekolah bertanda positif.

\section{Pengaruh Motivasi Kerja $\left(\mathrm{X}_{2}\right)$ terhadap Kinerja Guru $(\mathrm{Y})$}

Untuk pengaruh yang terjadi pada motivasi kerja terhadap kinerja guru, koefisien regresi yang terbentuk yaitu sebesar 0,821 yang mengartikan pengaruh motivasi kerja terhadap kinerja guru adalah signifikansi dengan kategori sangat kuat. Dari hasil perhitungan koefisien determinasi diperoleh $r_{x 2 . y}=0,821^{a}=0,674$ atau $67,4 \%$. Ini berarti sebesar $67,4 \%$ variansi kinerja guru dapat dijelaskan oleh motivasi kerja melalui persamaan regresi $Y=11,342+0,831 X_{2}$. Persamaan $Y=$ $11,342+0,831 \mathrm{X}_{2}$ mempunyai arti bahwa setiap peningkatan satu satuan skor motivasi kerja maka akan diikuti oleh kenaikkan skor kinerja guru sebesar 0,831 pada konstanta 11,342 .

Untuk menguji signifikansi regresi antara motivasi kerja $\left(\mathrm{X}_{2}\right)$ terhadap kinerja guru $(Y)$ digunakan rumus uji t. Harga t hitung $=11,342$ sedangkan $t$ tabel untuk uji 
dua pihak dengan $\mathrm{dk}=147, \alpha=0,05$ diperoleh harga $\mathrm{t}$ tabel $=1,655$. Karena $\mathrm{t}$ hitung $=11,342>\mathrm{t}$ tabel = 1,655 maka dapat disimpulkan bahwa terdapat hubungan yang signifikan. Dengan demikian hipotesis nol $\left(\mathrm{H}_{0}\right)$ ditolak, sebaliknya hipotesis alternatif $\left(\mathrm{H}_{\mathrm{a}}\right)$ diterima. Kesimpulannya adalah terdapat pengaruh motivasi kerja $\left(\mathrm{X}_{2}\right)$ terhadap kinerja guru $(Y)$.

Kemudian berdasarkan hasil $F$ hitung $=309,661>$ Ftabel 3,06 dengan taraf signifikansi 0,05 , maka $\mathrm{H}_{0}$ ditolak. Dengan demikian hipotesis kedua dalam penelitian ini diterima, artinya terhadap pengaruh yang signifikan motivasi kerja terhadap kinerja guru.

Pengaruh motivasi kerja terhadap kinerja guru menunjukkan hasil koefisien regresi yang positif dan signifikan. Ini berarti bahwa jika motivasi kerja diikuti secara baik, maka kinerja guru pun juga akan baik.

Hasil ini sesuai dengan penelitian yang dilakukan oleh Rahmawati (2011), dengan hasil analisis statistik menunjukkan bahwa kerja guru ekonomi SMA di Tegal termasuk dalam kategori tinggi (72,88\%). Persamaan dalam penelitian ini adalah sama-sama menggunakan motivasi kerja guru dan kinerja guru sebagai variabel. Perbedaan dalam penelitian ini adalah lokasi, sampel, dan variabel penelitian.

Hal ini sesuai dengan pendapat yang dikemukakan oleh Barnawi (2012:45) faktor - faktor yang mempengaruhi kinerja guru yakni : faktor internal kinerja guru adalah faktor yang datang dari dalam diri guru yang dapat mempengaruhi kinerjanya, contohnya ialah kemampuan, keterampilan, kepribadian, persepsi, motivasi menjadi guru, pengalaman lapangan dan latar belakang keluarga. Sedangkan faktor eksternal kinerja guru adalah faktor yang datang dari luar guru yang dapat mempengaruhi kinerjanya, contohnya ialah (1). Gaji (2). Sarana dan prasarana (3). Lingkungan kerja fisik (4). Kepemimpinan kepala sekolah.

Dengan demikian motivasi kerja yang tinggi dapat meningkatkan kinerja guru tersebut, hal ini di Sekolah Dasar Negeri di Kecamatan Dumai Barat Kota Dumai. Hal ini dibuktikan denga hasil analisis regresi bahwa koefisien motivasi kerja bertanda positif. 
Pengaruh Kepemimpinan Kepala Sekolah $\left(X_{1}\right)$ dan Motivasi Kerja $\left(X_{2}\right)$ terhadap Kinerja Guru (Y)

Untuk mengetahui kepemimpinan kepala sekolah dan motivasi kerja secara bersama-sama terhadap kinerja guru, koefisien regresi yang terbentuk yaitu sebesar 0,848 yang mengartikan kekuatan pengaruh kepemimpinan kepala sekolah dan motivasi kerja bersama-sama terhadap kinerja guru adalah sangat kuat. Dari hasil perhitungan koefisien determinasi adalah $r_{x 1 . x 2 . y}=0,848^{a}=0,720$ atau $72 \%$. Ini berarti sebesar $72 \%$ variansi kinerja guru dalam persamaan regresi berganda dapat dijelaskan oleh kepemimpinan kepala sekolah dan motivasi kerja secara bersamasama melalui persamaan regresi $Y=8,148+0,206 X_{1}+0,636 X_{2}$. Persamaan regresi $Y=8,148+0,206 X_{1}+0,636 X_{2}$ mempunyai arti bahwa setiap peningkatan satu satuan skor kepemimpinan kepala sekolah dan motivasi kerja secara bersamasama dapat meningkatkan skor kinerja guru masing-masing 0,206 dan 0,636 pada konstanta 8,148.

Berdasarkan hasil dari $\mathrm{F}$ hitung $=188,588>$ Ftabel $=3,06$, dengan taraf signifikansi 0,05 , maka $\mathrm{H}_{0}$ ditolak dan $\mathrm{H}_{\mathrm{a}}$ diterima yang menjelaskan bahwa terdapat pengaruh yang signifikan antara kepemimpinan kepala sekolah $\left(X_{1}\right)$ dan motivasi kerja $\left(\mathrm{X}_{2}\right)$ secara bersamaan mempengaruhi kinerja guru $(\mathrm{Y})$.

Hasil ini sesuai dengan penelitian yang dilakukan oleh Astuti (2014), hasil peneltian menunjukkan kinerja guru dipengaruhi oleh kepemimpinan kepala sekolah sebesar 18,8\%. Kinerja dipengaruhi Kompetensi Guru sebesar 24,9\% dan sisanya $75,1 \%$ dipengaruhi oleh faktor lain yang tidak diteliti dalam penelitian ini. 56,2\% Kinerja dipengaruhi Kepemimpinan Kepala Sekolah, Motivasi Kerja dan Kompetensi Guru dan sisanya $43,8 \%$ dipengaruhi oleh faktor lain yang tidak diteliti dalam penelitian ini. Dengan demikian dapat disimpulkan kepemimpinan adalah kemampuan seorang pemimpin dalam mempengaruhi, menggerakkan, memotivasi dan membimbing orang lain atau bawahannya dalam usaha mencapai tujuan.

Kemudian hasil penelitian ini juga diperkuat lagi oleh teori Menurut Timpe (1993:32) beberapa faktor yang mempengaruhi kinerja guru adalah : (1) lingkungan kerja, (2) motivasi kerja, (3) gaya kepemimpinan kepala sekolah, (4) perilaku, (5) sikap, dan (6) hubungan dengan sesama guru. Syadam (1996: 486) menyatakan 
faktor-faktor yang mempengaruhi kinerja seorang guru dalam melaksanakan pekerjaannya yaitu : (1) tingkat kependidikan, (2) pengalaman kerja, (3) lingkungan kerja, (4) peralatan atau sarana pendukung, (5) kepemimpinan, dan (6) motivasi kerja guru itu sendiri. Wibowo (2007:87) mengatakan bahwa kinerja guru dipengaruhi oleh pengetahuan, kemampuan, sikap, gaya kerja, kepribadian, minat, dasar-dasar nilai, kepercayaan dan gaya kepemimpinan kepala sekolah.

Jadi seorang kepala sekolah harus memiliki kepemimpinan yang kuat, apabila kepemimpinan yang dimiliki kepala sekolah terus diasah dan ditingkatkan otomatis akan memberikan efek positif pada kinerja guru disekolah. Kemudian dengan dorongan motivasi kerja yang kuat dapat meningkatakan kinerja guru disekolah, apabila terus diperbaharui dan ditingkatkan maka turut serta menjadi faktor yang memberikan sumbangsih nyata terhadap kinerja guru yang ada di sekolah tersebut. Dapat disimpulkan kedua aspek ini yaitu kepemimpinan kepala sekolah dan motivasi kerja merupakan faktor dominan penentu tercapainya kinerja guru yang baik.

\section{SIMPULAN}

1. Terdapat pengaruh positif dan signifikan antara kepemimpinan kepala sekolah terhadap kinerja guru Sekolah Dasar Negeri di Kecamatan Dumai Barat Kota Dumai. Artinya bila kepemimpinan kepala sekolah ditingkatkan maka kinerja guru akan meningkat, sebaliknya semakin rendah kepemimpinan kepala sekolah maka semakin rendahlah kinerja guru.

2. Terdapat pengaruh positif dan signifikan antara motivasi kerja terhadap kinerja guru Sekolah Dasar Negeri di Kecamatan Dumai Barat Kota Dumai. Artinya apabila motivasi kerja baik, maka kinerja guru tersebut akan baik pula untuk meningkatkan mutu pendidikan, sebaliknya semakin rendah motivasi kerja maka semakin rendahlah kinerja guru.

3. Terdapat pengaruh yang positif antara kepemimpinan kepala sekolah dan motivasi kerja terhadap kinerja guru Sekolah Dasar Negeri di Kecamatan Dumai Barat Kota Dumai. Artinya semakin baik kepemimpinan kepala sekolah dan motivasi kerja maka semakin meningkatlah kinerja guru. 
Dengan demikian dapat diketahui bahwa ketiga hipotesis yang diajukan penelitian dapat diterima yaitu kepemimpinan kepala sekolah dan motivasi kerja secara sendiri-sendiri maupun secara bersama-sama mempunyai pengaruh yang berarti dengan kinerja guru.

\section{DAFTAR PUSTAKA}

Dirjen Dikdasmen. (1998). etunjuk Penyelenggaraan. Musyawarah Kerja Pengawas Sekolah. Jakarta: Ditjen Dikdasmen,. Depdiknas. Direktorat Tenaga Kependidikan.

Hoy, W. K., \& Miskel, C. G. (1991). Educational administration, theory, research and practice. New York McGraw-Hill.

Husaini. (2010). Manajemen Teori, Praktik, dan Riset Pendidikan. Edisi 3. Jakarta: PT Bumi Aksara.

Mathis, R. L., \& Jackson, J. H. (2011). Human Resource Management (edisi. 10). Jakarta : Salemba Empat. Malayu S.P. Hasibuan. 2013

McShane, S. L., \& Von Glinow, M. A. (2008). Organizational behavior. Emerging realities for the workplace revolution. Boston, MA: McGraw Hill Irwin.

Putra, Z. H. (2019). Elementary teachers' knowledge on fraction multiplication: An anthropological theory of the didactic approach. Journal of Teaching and Learning in Elementary Education,2(1), 47-52. http://dx.doi.org/10.33578/jtlee.v2i1.6964

Rivai, V. (2009). Kepemimpinan dan Perilaku Organisasi, Cetakan ke-7. Jakarta, PT. Raja Grafindo Persada.

Rivai, V., \& Murni, S. (2009). Education Management; Analisis Teori dan Praktik. Jakarta: Rajawali Pers.

Sanusi, A. (2013). Kepemimpinan Pendidikan: Strategi Pembaruan, Semangat Pengabdian, Manajemen Modern. Nuansa Cendekia: Bandung.

Sari, F. A., \& Isjoni, Y. R. (2021). Pengaruh Supervisi Akademik Kepala Sekolah terhadap Profesionalisme Guru Mata Pelajaran Ekonomi SMA Negeri di Kabupaten Kampar. Tunjuk Ajar: Jurnal Penelitian IImu Pendidikan, 4(1), 5772.

Sigit, S. (1998). Teori kepemimpinan dalam manajemen. Yogyakarta: Armurrita.

Simamora, S. (2010). Manajemen Sumber daya Manusia. Yogyakarta: STIE YKPN.

Wibowo, W. (2007). Manajemen Kinerja. Jakarta: Penerbit PT. Rajagrafindo Persada.

Winardi. (2010). Psikologi Industri dan Organisasi. Depok: UI-Press. 